\title{
Nitrogen Fixation by Sporulating Sulphate-reducing Bacteria Including Rumen Strains
}

\author{
By J. R. POSTGATE \\ A.R.C. Unit of Nitrogen Fixation, University \\ of Sussex, Brighton, BNI $9 Q J$ \\ (Accepted for publication 23 June 1970)
}

The acetylene test for nitrogen fixation has been an important tool in reassessing the ability of various groups of micro-organisms to fix nitrogen (Parejko \& Wilson, I968; Millbank, 1969; Hill \& Postgate, I969). As a result of this reassessment, it has been found that several aerobic genera such as Azotomonas, Pseudomonas, Nocardia, Pullularia and yeasts probably do not fix $\mathrm{N}_{2}$; on the other hand, nitrogen fixation has proved to be far more widespread among the sulphate-reducing bacteria of the genus Desulfovibrio than was earlier thought (Reiderer-Henderson \& Wilson, 1970). This communication reports evidence for fixation by type strains of mesophilic, spore-forming, sulphate-reducing bacteria, genus Desulfotomaculum (Campbell \& Postgate, 1965), including strains originating from the rumens of hay-fed sheep. Some data with type strains of Desulfovibrio are included to supplement the findings of Reiderer-Henderson \& Wilson (I970).

Desulfotomaculum ruminis and Dm. orientis, as well as the Desulfovibrio species, were incubated at $30^{\circ}$ and Dm. nigrificans at $55^{\circ}$ in medium B (Postgate, 1966). Growth and acetylene reduction in N-deficient medium was tested for in Pankhurst (I967) tubes as described by Campbell \& Evans (I969), except that gassing with $\mathrm{N}_{2}$ was omitted and instead, about $2 \mathrm{~h}$. after setting up, Io ml. $\mathrm{N}_{2}$ were injected through the side arm to replace oxygen absorbed by the pyrogallol plug. The $\mathrm{N}$ deficient medium was a variant of medium B: ammonium chloride was omitted and the trace-element mixture specified by Postgate (I966) was included. In all tests a tube containing $100 \mu \mathrm{g}$. yeast extract $/ \mathrm{ml}$. (cf. Reiderer-Henderson \& Wilson, 1970) was included and also one with $2 \mathrm{mg}$. $\mathrm{NH}_{4} \mathrm{Cl} / \mathrm{ml}$. to repress nitrogenase synthesis. When growth was obvious because of blackening of the culture (the $1 \%$ to $10 \%$ innoculum carried over sufficient fixed $\mathrm{N}$ for marginal growth), $2.5 \mathrm{ml}$. of $\mathrm{N}$-free or $\mathrm{NH}_{4}$-containing medium was injected aseptically into the culture and, 24 to $48 \mathrm{~h}$. later, I ml. of $\mathrm{C}_{2} \mathrm{H}_{2}$, freshly prepared from $\mathrm{Ca}_{2} \mathrm{C}_{2}+\mathrm{H}_{2} \mathrm{O}$, was injected via the side arm. Three to $5 \mathrm{ml} . \mathrm{N}_{2}$ were then injected to allow an excess of gas for sampling; gas samples were removed at intervals up to 3 days and analysed for ethylene by vapour-phase chromatography as reported elsewhere (Hill \& Postgate, 1969). Progressive formation of ethylene, which did not take place in cultures containing $\mathrm{NH}_{4} \mathrm{Cl}$, was taken as presumptive evidence for the presence of nitrogenase; negative cultures were tested again after 5 days, before discarding.

Though cultural tests had earlier failed, this procedure confirmed the presence of nitrogenase in the marine strain of Desulfovibrio desulfuricans, NORWAY 4, in D. vulgaris, strain HILDENBOROUGH, and in D. gigas, as reported by Reiderer-Henderson \& Wilson, 
(I970). D. desulfuricans, strains BERRE SOL (NCIB 8388) and BERRE EAU (NCIB 8387) grew readily in N-free media as claimed by Le Gall, Senez \& Pichinoty (I959) and reduced acetylene readily; the holotype strain of D. desulfuricans, strain ESSEX 6 (NCIB 8307), reduced acetylene and so did a strain of unusual semilunar morphology provided by Dr H. Veldkamp; type strains of $D$. africanus (strain BENGHAZI; NCIB 840I) and $D$. salexigens (strain BRITISH GUIANA; NCIB 8403) did not, nor did a second halotolerant strain of $D$. desulfuricans (strain EL AGHEILA A; NCIB 8309). Acetylene reduction, when observed, was inhibited by $\mathrm{NH}_{4} \mathrm{Cl}$, usually completely, but in one test (see below), only partially. It was not consistently affected by the small amount of yeast extract: sometimes yeast extract accelerated this reaction, sometimes the reaction was slowed.

Table I. Acetylene reduction and nitrogen fixation by Desulfotomaculum species For procedures see text. ' $\mathrm{Y}$ ' signifies Ioo $\mu \mathrm{g}$. yeast extract $/ \mathrm{ml}$.

\begin{tabular}{|c|c|c|c|c|c|c|c|}
\hline \multirow{3}{*}{ Organism } & \multicolumn{4}{|c|}{ nmoles $\mathrm{C}_{2} \mathrm{H}_{4}$ produced $/ 7 \mathrm{ml}$. culture } & \multirow{2}{*}{\multicolumn{2}{|c|}{$\begin{array}{c}\mu \mathrm{g} . \mathrm{N} / \mathrm{ml} \text {. after } \mathrm{r} 2 \\
\text { days in medium }+\mathrm{Y} \text {, } \\
\text { control acidified } \\
\text { with } \mathrm{H}_{2} \mathrm{SO}_{4}\end{array}$}} & \multirow{3}{*}{$\begin{array}{l}\text { Atom } \%{ }^{15} \mathrm{~N} \\
\text { excess after } \\
\text { I9 days under } \\
\text { Ar }+0.1 \text { atm. } \\
99 \%{ }^{15} \mathrm{~N}_{2} \text { in } \\
\text { medium }+\mathrm{Y}\end{array}$} \\
\hline & \multicolumn{2}{|c|}{ After $\mathrm{I}$ day } & \multicolumn{2}{|c|}{ After 3 days } & & & \\
\hline & $-Y$ & $+Y$ & $-\mathbf{Y}$ & $+\mathrm{Y}$ & Control & Culture & \\
\hline Dm. ruminis & & & & & & & \\
\hline (NCIB IO,I49) & 64 & 85 & 488 & 484 & $22 \cdot 4$ & $27 \cdot 6$ & 0.009 \\
\hline (NCIB 8542) & 13.9 & $9 \cdot 8$ & 148 & 67 & $24 \cdot 6$ & $27 \cdot 6$ & 0.010 \\
\hline $\begin{array}{l}\text { Dm. orientis } \\
(\mathrm{NCIB} 8382)\end{array}$ & & I2.? & $2 \cdot 3$ & 87 & 22.8 & 28.0 & 0.027 \\
\hline Dm. nigrificans & & & & & & & \\
\hline (NCIB 8395) & 0 & 0 & 0 & 0 & - & - & - \\
\hline
\end{tabular}

Desulfovibrio desulfuricans BERRE sol cultures produced $\mathrm{I} 2$ to $330 \mathrm{nmole} \mathrm{C}_{2} \mathrm{H}_{4}$ in $\mathrm{I}$ day in $\mathrm{I} 2$ comparable tests; the amount of fixed $\mathrm{N}$ in a culture increased from 12.6 to $15.86 \mu \mathrm{g}$. $\mathrm{N} / \mathrm{ml}$. over I I days; another reached 0.395 atom $\%$ excess ${ }^{15} \mathrm{~N}$ in 19 days.

Table I lists the results of tests on Desulfotomaculum species. Like ReidererHenderson \& Wilson (1970), I obtained no evidence of fixation by the thermophile Dm. nigrificans. The two strains of Dm. ruminis and the one strain of Dm. orientis showed unequivocal activity, completely repressed by $\mathrm{NH}_{4} \mathrm{Cl}$, except in one out of three tests with $D m$. orientis where repression was only partial. The values for ethylene produced given in Table I cannot be taken as measures of the relative activities of the strains because the time at which to inject acetylene was judged subjectively and the population densities were unlikely to have been similar. From several experiments Desulfotomaculum species appeared to reduce acetylene at about Io \% of the rate usually found with BERRE strains of Desulfovibrio. Assuming $\mathrm{N}_{2}$ is reduced one-third as rapidly as $\mathrm{C}_{2} \mathrm{H}_{2}$, one can calculate approximate rates of $\mathrm{N}_{2}$ fixation to which the figures for acetylene reduction correspond: for Desulfotomaculum species they would be in the region of 2 to $5 \mu \mathrm{g}$. N fixed/ml. culture. Table I includes analytical data and tests with ${ }^{15} \mathrm{~N}_{2}$ which, though not impressive on their own, support the presumptive evidence of the acetylene test and establish nitrogen fixation among the mesophilic members of the genus Desulfotomaculum.

Reiderer-Henderson \& Wilson (I970) deduced from their experiments that $\mathrm{N}_{2}$ fixation is more widespread than hitherto thought in the genus Desulfovibrio. My 
experiments support this view, and the relatively small fixations obtained by analytical or isotopic tests on cultures taken direct from ammonia-containing media may offer a partial reason for earlier difficulties in detecting nitrogen fixation among members of this genus. The ability of the two strains of Desulfotomaculum ruminis to fix $\mathrm{N}_{2}$ is of ecological interest in that both strains were isolated from the rumens of sheep (Coleman, I960), though whether they represent normal rumen inhabitants or itinerants introduced with food is uncertain. Bergersen \& Hipsley (I970) have evidence that facultatively anaerobic bacteria in the intestines of men and guinea pigs may, in certain circumstances, be actively fixing nitrogen. The rumen of a ruminant mammal might, in conditions in which the dietary nitrogen was low, be a logical environment in which commensal $\mathrm{N}_{2}$-fixation by anaerobes could take place and such fixation might be of benefit to the host animal.

Miss K. Williams assisted with part of this work, and Mr E. Kavanagh performed the nitrogen analyses. ${ }^{15} \mathrm{~N}_{2}$ was estimated by mass spectrometry by $\mathrm{Dr} \mathrm{C}$. W. Crane (Queen Elizabeth Hospital, Birmingham).

\section{REFERENCES}

Bergersen, F. J. \& Hipsley, E. H. (1970). Presence of $\mathrm{N}_{2}$-fixing bacteria in the intestines of men and animals. Journal of General Microbiology 60, 6I-66.

Camprell, L. L. \& Postgate, J. R. (1965). Classification of the spore-forming, sulphate-reducing bacteria. Bacteriological Reviews 29, 359-363.

Campbell, N. E. R. \& Evans, H. J. (I969). Use of Pankhurst tubes to assay acetylene reduction by facultative and anaerobic nitrogen-fixing bacteria. Canadian Journal of Microbiology 15, I 3421434.

Coleman, G. S. (1960). A sulphate-reducing bacterium from the sheep rumen. Journal of General Microbiology 22, 423-436.

Hill, S. \& Postgate, J. R. (1969). Failure of putative nitrogen-fixing bacteria to fix nitrogen. Journal of General Microbiology 58, 277-285.

Le Gall, J., Senez, J. C. \& Pichinoty, F. (I959). Fixation de l'azote par les bactéries sulfatoréductrices. Annales de l'Institut Pasteur, Paris 96, 223-230.

Millbank, J. W. (1969). Nitrogen fixation in moulds and yeasts-a reappraisal. Archiv für Mikrobiologie 68, 32-39.

Pankhurst, E. S. (1967). A simple culture tube for anaerobic bacteria. Laboratory Practice 16, $58-59$.

Parejko, R. A. \& Wilson, P. W. (1968). Taxonomy of Azotomonas species. Journal of Bacteriology 95, I43-r 46.

PostGate, J. R. (1966). Media for sulphur bacteria. Laboratory Practice 15, 1239-1244.

Remerer-Henderson, M. A. \& Wilson, P. W. (1970). Nitrogen fixation by sulphate-reducing bacteria. Journal of General Microbiology 6r, 27-32. 